\title{
Epoxidation of aminometradin (l-allyl-3-ethyl-6-amino uracil) using tetraoxochromate(VI) acid, trifloroperacetic acid and hydrogen peroxide as oxidants, catalyzed by dioxovanadium $(V)$ ion
}

\author{
E.M. ODIN *, P.K. ONOJA and B.O. AKABUEZE
}

Department of Pure and Industrial Chemistry, Kogi State University, Anyigba, Nigeria.

*Corresponding author, E-mail: odinem2005@yahoo.com; Tel: +234 08138637104

\begin{abstract}
This paper compared the epoxidation of aminometradin (1-allyl-3-ethyl-6-amino uracil) (1) using tetraoxochromate(VI) acid, trifloroperacetic acid and hydrogen peroxide as oxidants. Tetraoxochromate(VI) and trifloroperacetic acids yielded epoxides in low yields and environmentally unfriendly products. Epoxidation with $\mathrm{H}_{2} \mathrm{O}_{2}$ in the presence of dioxovanadium $(\mathrm{V})$ ion as catalyst improved the yield. However, the presence of pyridine-N-Oxide as co-catalyst, increase in the amount of $\mathrm{H}_{2} \mathrm{O}_{2}$ and temperature gave epoxidation reaction that proceeded to near completion. (9a-o), indicating that $\mathrm{H}_{2} \mathrm{O}_{2}$ is a highly reactive oxidant for the epoxidation of aminometradin, and pyridine-N-Oxide catalyzed the formation of epoxides in quantitative yields.

(C) 2013 International Formulae Group. All rights reserved.
\end{abstract}

Keywords: Epoxidation, Aminometradin, Dioxo vanadium(V) ion, Pyridine N-oxide, Co-catalyst.

\section{INTRODUCTION}

Epoxidation has advanced in ten years from little more than a laboratory curiosity to a commercial chemical process. Epoxidized fatty esters derived from such natural oils as soybean and from such synthetic oils as butyl oleate, are major products of epoxidation technology (Latourette et al., 2012). These are principally used as secondary plasticizers for polyvinyl chloride and copolymers, to which they impact a spectrum of properties including heat and light stability, superior aging, and low-temperature flexibility (Gall and Greenspan, 2012). Aminometradin (1- allyl-3ethyl-6-aminouracil) belongs to the pryimidine group of heterocyclic compounds.
The growth in the chemistry of aminouracil during the last decade is due to the search by chemists for new diuretic drugs. Aminometradin is a diuretic drug which increases urine and solute excretion from the kidney. To be therapeutically useful, a diuretic should increase the output of sodium as well as of water. Diuretics are normally required to remove oedema fluid which is composed of water and solutes, of which sodium is the most important (Abdillahi and James, 2003; Gerd-Jan et al., 2007; Lawrence et al., 1998). Accumulation of sodium in the kidney will normally lead to high blood pressure. Each day the body produces about 180 litres of glomerular filterate which is 
modified in its passage down the renal tubules to appear as 1.5 litres of urine. The diuretic drugs act on the tubule to alter body fluid and electrolyte balance (Lawrence et al., 1998; Tayde et al., 2011). In this paper, we report the synthesis of new aminometradin derivatives for further assessment of their therapeutic activities as diuretics. The main objective of this work is to establish an oxidant that will give a green epoxidation of aminometradin in quantitative yields. Their epoxidation was studied using three types of oxidants (Adolfson, 2004; Rao, 2012). The expected epoxides can be transformed into a large variety of compounds via regio- and stereoselective ring opening (Clementina et al., 2006; Latourette et al., 2012). Tetraoxochromate(V1) acid, trifloroperacetic acid and hydrogen peroxide were employed as oxidants. The epoxidation reaction was catalysed by dioxovanadium(V) ion and pyridine N-oxide acting as co-catalyst (Golchoubian and Nemati, 2005; Guodong and Espensor, 2005; Petrovic et al., 2012). The reaction was carried out at different temperatures and reaction conditions.

\section{MATERIALS AND METHODS}

All chemicals were obtained from different commercial sources (Lavans, Aldrich, Merck) and were used without further purification. The melting points (m.p) were determined on a SMP3 melting point apparatus and are reported in ${ }^{0} \mathrm{C}$ uncorrected. Column chromatography was performed on Scharlau silica gel 60 (70-230 mesh). The ${ }^{1} \mathrm{H}$ and ${ }^{13} \mathrm{C}-\mathrm{NMR}$ spectra were recorded on a Varian Germini 2000 spectrophotometer operating 200 and $50 \mathrm{MHz}$ respectively. Chemical shifts were recorded as $\delta$ values in ppm referenced to the solvent. HPLC separations were performed on a Bulk Scientific 500 apparatus using a reverse phase Lichrospher 100RP-18 (5 $\mu \mathrm{m})$ column, at room temperature ( eluent: methanol / water -
8:2, V/V ). The Infrared ( IR) spectra were recorded in $\mathrm{cm}^{-1}$ on a Bulk Scientific 500 spectrophotometer.The mass spectra were recorded on a Shimadzu GCMS-QP-1000 EX mass spectrometer at $70 \mathrm{eV}$ and elemental analysis for $\mathrm{C}, \mathrm{H}, \mathrm{N}$ on a Perkin-Elmer $\mathrm{CHN}$ Analyzer 2400.

\section{Epoxidations of aminometradin (1-allyl-3- ethyl-6-aminouracil) \\ Oxidation using tetraoxochromate(VI)} acid: $785 \mathrm{mg}, 5 \mathrm{mmol}$ of aminometradin (1) was dissolved in chloroform $(20 \mathrm{ml})$. While stirring, $100 \mathrm{ml}$ of tetraoxochromate(VI) acid $(0.090 \mathrm{mmol})$ was gradually added at $25{ }^{0} \mathrm{C}$. The mixture was separated using column chromatography (eluent: n-hexene/ ethylacetate $=5: 1.5, \mathrm{v} / \mathrm{v})$. The yield was 25 $\operatorname{mg}(3.8 \%)$ epoxide $(2)$.

\section{Oxidation using trifluoroperacetic acid}

$90 \mathrm{ml}$ of trifluoroperacetic acid $(0.75$ mmol) was added to a solution of $500 \mathrm{~g}, 3.2$ mmol aminometradin (1) in chloroform (15 $\mathrm{ml})$. The addition was done while stirring continuously for $1 \mathrm{hr}$ at $25{ }^{\circ} \mathrm{C}$. The mixture was also separated using column chromatography (eluent: n-hexane/ ethylacetate $5: 2, \mathrm{v} / \mathrm{v})$. The yield was $28 \mathrm{mg}$ $(5.6 \%)$ epoxide (8).

\section{Oxidation using hydrogenperoxide}

\section{Oxidation without pyridine- $\mathrm{N}$-oxide (catalyst)}

Aminometradin (1) $[500 \quad \mathrm{mg}, \quad 3.2$ $\mathrm{mmol}]$ and vanadium reagent-VO (acac) $)_{2}(3.2$ mmol) were dissolved in a 1:1 mixture of chloroform/methol (14 ml). This solution was added to $35 \%$ aqueous $\mathrm{H}_{2} \mathrm{O}_{2}(0.4 \mathrm{ml}, 12$ mmol). The reaction mixture was stirred at 25 ${ }^{0} \mathrm{C}$ for $1 \mathrm{hr}$. The mixture was separated by preparative silica gel thin layer chromatography (eluent: 40-60 petroleum ether/ethyl acetate $(2: 3, \mathrm{v} / \mathrm{v})$ to give trace quality of epoxide (9a). The yield/effective 
yield are 9a $(0.60 \%, 11.5 \%)$ (Table 2, Entry 1).

Oxidation using Pyridine-N-oxide (co-
catalyst)

In the case of epoxide 9b-g (Table 2, Entries 2-7), the catalyst (3.2 $\mathrm{mmol})$ was added to a solution of the appropriate aminometradin (500 mg, $3.2 \mathrm{mmol}$ ) and pyridine-N-oxide $(0.64 \mathrm{mmol})$ in acetonitrile (10 ml). $35 \%$ aqueous $\mathrm{H}_{2} \mathrm{O}_{2}(0.4 \mathrm{ml}, 12 \mathrm{mmol})$ was added and the mixture stirred at $25{ }^{\circ} \mathrm{C}$ for a period ranging between $60 \mathrm{~min}$ to $300 \mathrm{~min}$. The mixture was separated by HPLC. The yields/effective yields of the epoxidation are shown in Table 2, Entries 2-7 (9b-g epoxide).

Epoxide 9i-j (Table 2, Entries 9-10) were prepared using an increased amount of $\mathrm{H}_{2} \mathrm{O}_{2}$. As described above, to the mixture containing the catalyst $(3.2 \mathrm{mmol})$, aminometradin $(3.2 \mathrm{mmol})$ and pyridin-Noxide $(0.64 \mathrm{mmol})$ were added to $35 \%$ aqueous $\mathrm{H}_{2} \mathrm{O}_{2}(16 \mathrm{mmol})$. The mixture was stirred at $50{ }^{\circ} \mathrm{C}$ for $60 \mathrm{~min}$. The separation was done using HPLC as above .The yields/effective yields are $(50.2 \%, 70.9 \%$ and $60 \%, 75 \%$ ) (Table 2, Entries 9-10).

Similarly, the remaining (Table 2, Entries 11-15) epoxides 9k-n were prepared while varying the quantity of $\mathrm{H}_{2} \mathrm{O}_{2}$ with reaction period.

\section{RESULTS}

First, aminometradin (1) was epoxidized with tetraoxochromate(VI) acid. The acid condensed with the aminometradin (1) to give epoxide (2) in trace quantity (Table 1, Entry 1) Scheme 1.

Another possible mechanism is given in Scheme 2. The initial step was the formation of a tetraoxochromate(VI) acid aminometradin $\pi$ complex (3). This led to the formation of a four-centered cyclic organochromium intermediate (4) via a $[2+2]$ interaction between the aminometradine and the oxo group on the chromium. The cyclic intermediate (4) yielded the epoxide precursor (5) by reductive elimination process which finally gave the cis - epoxide (2) (Goug et al., 2006; Mungroo et al., 2008; Ojinaka, 2001) (Scheme 2).

The result revealed low yield of epoxide, accumulated byproducts and unreacted starting material. The reaction did not show a "green" oxidation system.

The epoxidation of aminometradin (1) was equally tested with trifloroperacetic acid. (Table 1, Entry 2). The result gave cisepoxide (8) in low yield and the reaction occurred very slowly (Scheme 3 ).

The epoxidation of aminometradin (1) was also investigated with alkaline hydrogen peroxide with dioxovanadium(V) ion as catalyst in the presence of pyridine $\mathrm{N}$-oxide as co-catalyst. The reaction was carried out at different temperatures, concentration of $\mathrm{H}_{2} \mathrm{O}_{2}$ and reaction period. Scheme 4 showed that attack of hydrogen peroxide is stereo selective and did not occur via a cyclic transition state as in trifloroperacetic acid.

The aminometradine (1) was equally reacted with alkaline hydrogen peroxide in the presence of dioxovanadium(V) ion as the catalyst and at room temperature. The result (Table 2, Entry 1) was trace quantity of epoxide and a high amount of unreacted aminometradin (1) (Clementina et al., 2006; Dinda et al., 2008). The substrate (1) was further treated with alkaline hydrogen peroxide using the catalyst and pyridine $\mathrm{N}$ Oxide as co-catalyst. Table 2 (Entries 2-7) showed an appreciable amount of epoxide. It was also noted that the yield decreased with increase in the reaction period. (Table 2 Entries 2-7).

The aminometradin was later treated with an increase amount of hydrogen peroxide, at elevated temperature. Table 2, Entries 8 and 9 revealed that the epoxidation proceeded to near completion at elevated temperature. 
The structural assignments of the epoxyaminometradin were based upon spectral and microanalytical data. The IR spectral absorption bands at $1715-1725 \mathrm{~cm}^{-1}$ suggested the presence of carbonyl groups in the epoxides. The stretching vibration bands at 3450 and $3300 \mathrm{~cm}^{-1}$ were recorded for $\mathrm{NH}_{2}$ absorption. The $\mathrm{C}-\mathrm{O}-\mathrm{C}$ stretching vibration at $830 \mathrm{~cm}^{-1}$ revealed that the hydrogen atoms are in a cis-position.

The epoxyaminometradin could be identified by the singlet at $\delta=6.14-6.24$ ppm corresponding to the resonance of $6-\mathrm{H}$. Important information from the ${ }^{1} \mathrm{H}$ and ${ }^{13} \mathrm{C}$ NMR spectral were the resonances assigned to the hydrogens in the $\mathrm{C}-\mathrm{O}-\mathrm{C}$ and the carbon atoms. The hydrogen $\mathrm{H}(\delta=4.38-4.63 \mathrm{ppm})$ and the carbon $\mathrm{C}(\delta=57.3-59.8 \mathrm{ppm})$.

The most important characteristics of the ${ }^{13} \mathrm{C}$ NMR spectral of the epoxyaminometradin were the signals of the carbonyl carbons. The resonance at $\delta=182.6$ $181.7 \mathrm{ppm}$ was used to identify this compound.

Further proof came from the ${ }^{1} \mathrm{H}$ NMR spectra which showed appearance of a broad $6 \mathrm{H}$ signal belonging to $\mathrm{NH}_{2}$ and two sharp $3 \mathrm{H}$ signals assigned to $\mathrm{C}_{2} \mathrm{H}_{5}$.Anal. Calcd. $C_{9}$ $\mathrm{H}_{13} \mathrm{~N}_{3} \mathrm{O}_{3}$ (211.221): C,51.18. H,6.23. N,19.89. Found C,51.21. H,6.28. N,19.93<smiles>C=CCn1c(N)cc(=O)n(CC)c1=O</smiles> 


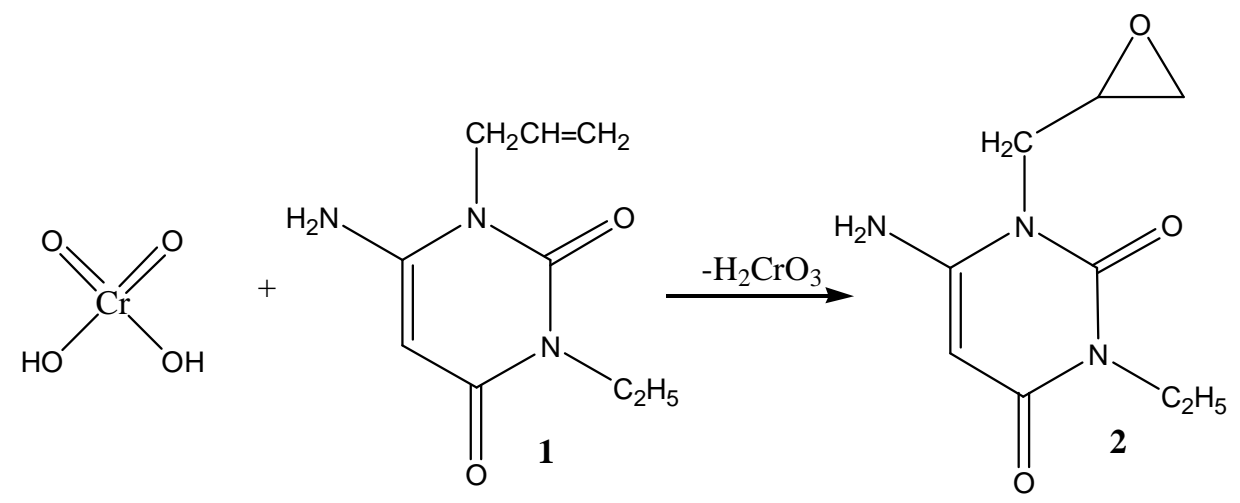

Scheme 1
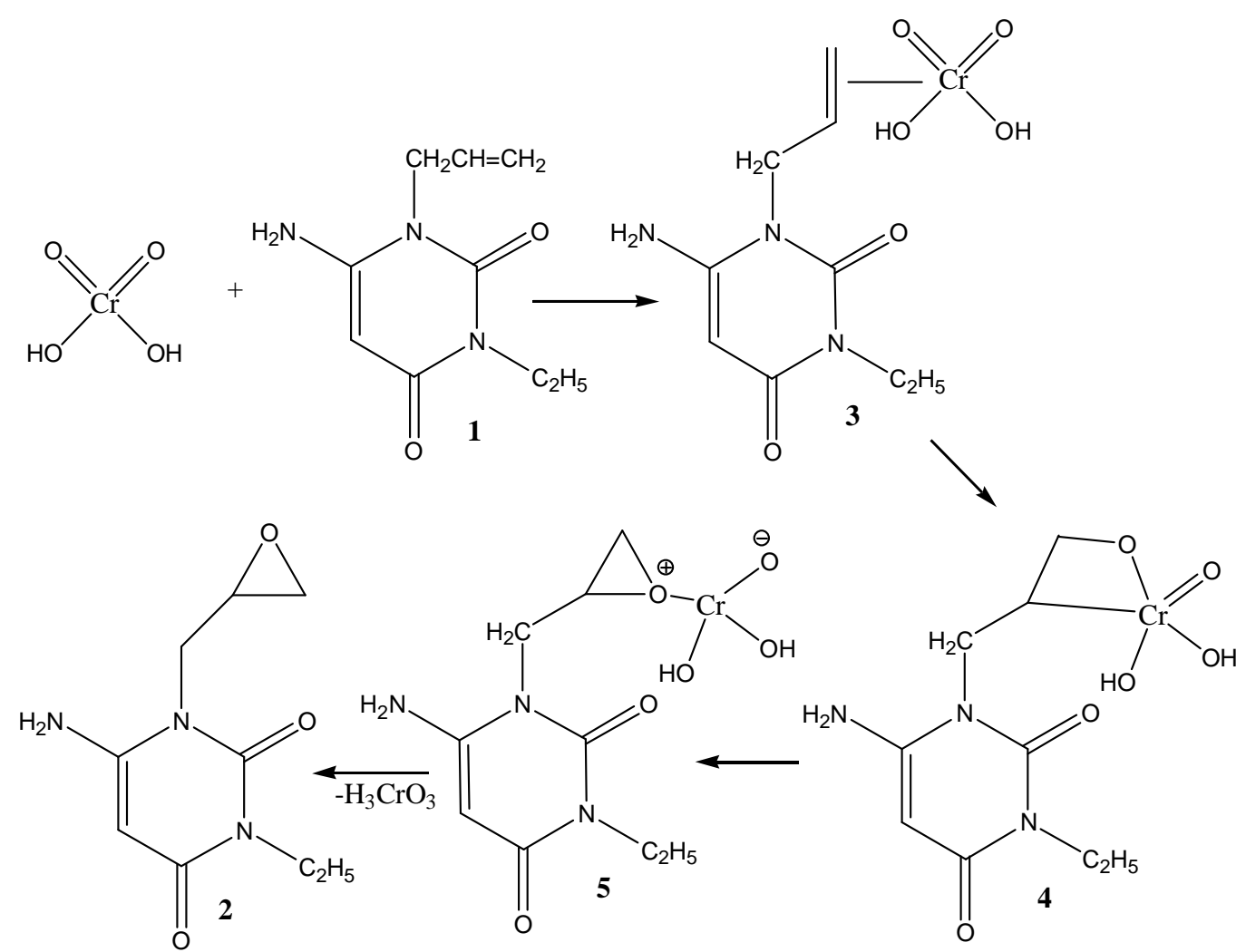

Scheme 2 
<smiles>C=CCn1c(N)cc(=O)n(C)c1=O</smiles>

Scheme 3

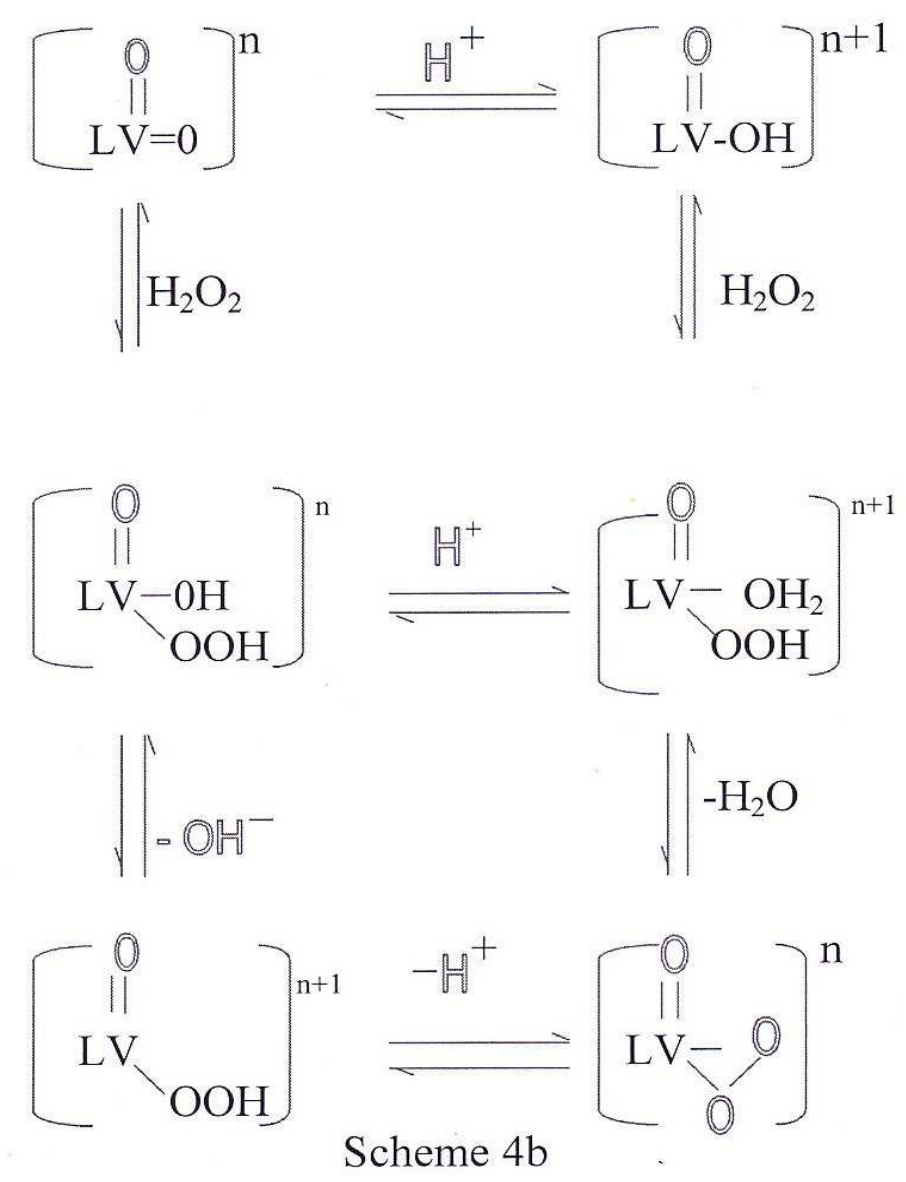


E.M. ODIN et al. / Int. J. Biol. Chem. Sci. 7(4): 1735-1744, 2013

Table 1: Epoxidation of aminometradin using tetraoxochromate(VI) and trifloroperacetic acids as oxidants.

\begin{tabular}{|c|c|c|c|c|c|c|c|}
\hline Entry & $\begin{array}{c}\text { Tetraoxochromate(VI) } \\
\text { acid (mg) }\end{array}$ & $\begin{array}{c}\text { Trifloper } \\
\text { acetic acid (mg) }\end{array}$ & Time (min) & Temp. $\left({ }^{\circ} \mathbf{C}\right)$ & Conversion (\%) & $\begin{array}{c}\text { Yield } \\
(\%)\end{array}$ & Effective Yield (\%) \\
\hline 1 & & Absent & 60 & 25 & 12.9 & 3.8 & 29.46 \\
\hline 2 & Absent & & 60 & 25 & 15.3 & 5.6 & 36.60 \\
\hline
\end{tabular}

Table 2: Epoxidation of aminometradin using dioxovanaduim(v) ion as catalyst and hydrogen peroxide as oxidant.

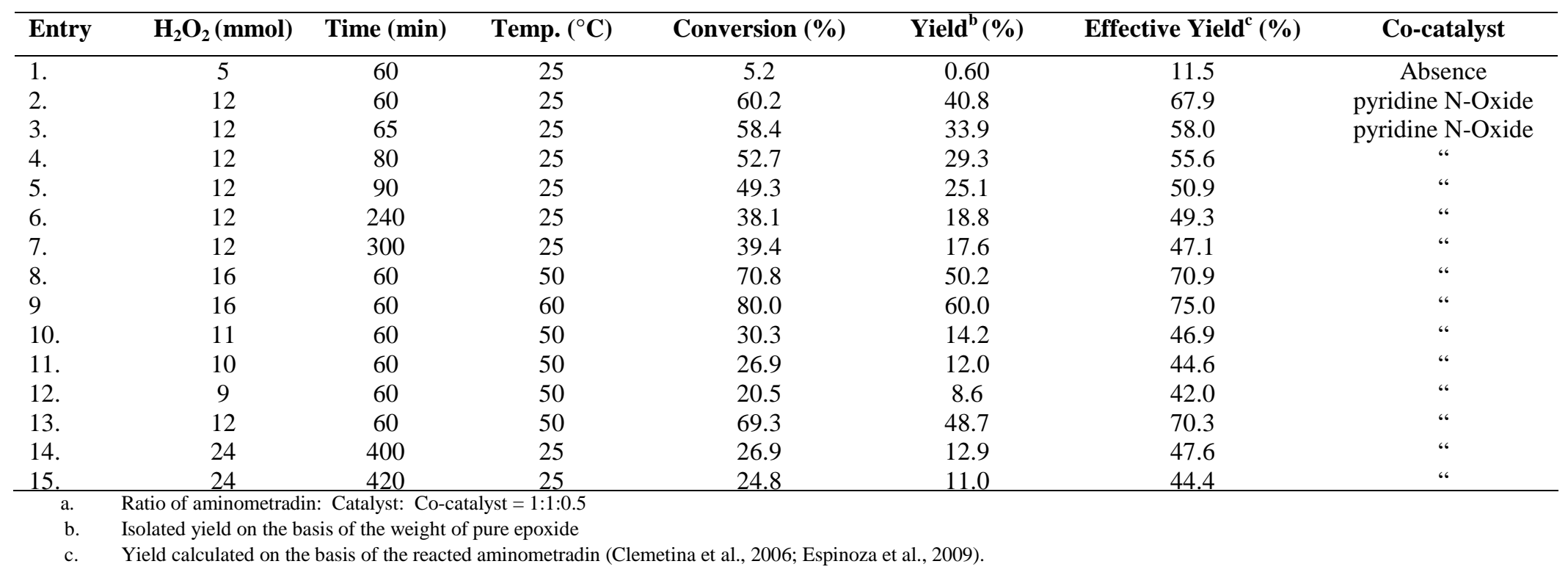




\section{DISCUSSION}

The mechanism (Scheme 1) of epoxidation of the olefin involved a direct attack of the aminometradin (1) on the oxygen end of the tetraoxochromate(VI) acid. The reaction gave a cis-epoxide which resulted from the direct attack on the heteroatom ligand (Hamid and Farid, 2007; Ojinaka, 2001; Rosana et al., 2009; Shangde et al., 2011) (Scheme 1).

The epoxidation with trifloroperacetic acid gave large accumulation of trifloro acetic acid and unreacted aminometradin. The peracid is believed to have attacked the aminometradine (1) from the less hindered side. From Scheme 3, the proton of the $\mathrm{OH}$ group of the peracid is hydrogen bonded to the oxygen of the $\mathrm{C}=\mathrm{O}$ group (6). The weak bond of the trifluoroperacetic acid breaks and the $\mathrm{C}-\mathrm{O}$ bonds of the epoxide was formed. (Scheme 3).

Therefore, it can be said that tetraoxochromate(VI) acid and trifluoroperacetic acid have little synthetic value in the epoxidation of aminometradine (1-alyl-3-ethyl-6-aminouracil). This came from the fact that the epoxidation with the oxidants gave product mixtures, unreacted substrate and environmentally unfriendly products (Table 1, Entries 1 and 2). (Cai et al., 2008; Clementina et al., 2006; Mangoroo et al., 2008).

The main problem associated with hydrogen peroxide oxidant was hemolytic cleavage of the weak O-O bond, which led to the formation of radicals and therefore indiscriminate oxidation (Clemetinal et al., 2006; Espinoza et al., 2009; Goud et al., 2007; Leveneur et al., 2009). One possible solution was the use of metal-containing catalyst such as vanadium $(\mathrm{V})$ complex, which gave reactive metal-oxo compounds in the presence of hydrogen peroxide as terminal oxidant.

The mechanism is that the $\mathrm{H}_{2} \mathrm{O}_{2}$ and dioxo-vanadium(V) ion combine to form oxoperoxovanadium complex which are known for their oxidizing properties (Butter et al., 1994; Campanella et al., 2007; Dinda et al., 2008). According to (Goud et al., 2007;
Mungoroo et al., 2008; Pecoraro et al., 1978), the peroxide binds either to a protonated form of the vanadium complex or to the complex itself (Scheme 4b). Subsequent loss of a hydroxide or water molecule and rapid rearrangement result in the formation of the oxoperoxo vanadium complex.

The role of pyridine N-oxide as cocatalyst is that, apart from acting as axial ligand for the transition metal catalyst, it also improves the efficiency of the catalyst.

It was further observed that at concentration of hydrogen peroxide lower than $12 \mathrm{mmol}_{2} \mathrm{O}_{2}$, the conversion decreased with decrease in concentration even at high temperature (Table 2, Entries 10-12). However, large excess of hydrogen peroxide did not improve the conversion rate. This is probably due to lower temperature and prolonged reaction period (Table 2, Entries 14-15). This was proved by the best result (75.0\% effective yield) which was achieved using excess of hydrogen peroxide at elevated temperature (Table 2 Entry 9). In all the expoxidation reactions, double epoxidation was prevented. It was reported by Sheng and Sharpless (1970) that when double bonds are epoxidised by peroxyacids or by hydroperoxides, the most electron rich double bond (that with the most alkyl substituents) is selectively attacked, hence the terminal double bond was epoxidised.

\section{Conclusion}

The possibility of epoxidation of aminometradin using tetraoxochromate(VI) acid, trifluoroperacetic acid and hydrogen peroxide have been verified. We also compared the epoxidation process using these oxidants. Due to the low reactivity of the substrates and environmentally unfriendly products from these oxidants, epoxidation with $\mathrm{H}_{2} \mathrm{O}_{2}$ in the presence of dioxovanadiun( $\mathrm{V}$ ) ion and pyridine-N-Oxide as co-catalyst is recommended. However, the percentage conversion was achieved at an increased amount of $\mathrm{H}_{2} \mathrm{O}_{2}$ and elevated temperature. 


\section{ACKNOWLEDGEMENTS}

The authors are grateful to Chemistry Laboratory, Kogi State University for the spectroscopic and elemental analysis and Mr. Paul Ojodale Samuel for Secretarial Assistance.

\section{REFERENCES}

Abdillahi OB, James H E. 2003. Epoxidation reactions with urea-hydrogen peroxide catalyzed methyltrioxorhenium(VII) on nobia. J. Mol. Cat., 200: 43-47.

Adolfsson, H. 2004. Modern Oxidation Methods, Bäckvall JE (ed). Wiley: Weinheim; 21-50

Butler A, Clague, MJ. Meister GE. 1994. Oxidation catalysis with high-valent vanadium complexes. Chem. Rev., 94: 625-638.

Cai C, Dai H., Chen R., Su C, Xu X, Zhang, S, Yang L. 2008. Studies on the kinetics of insitu epoxidation of vegitable oil. Europ. J. Lipid Sc. Tech., 110(4): 341346.

Campanella, A, Baltanas M. 2007. Degradation of oxirane ring of epoxidized vegetable oils in a liquid-liquid solid heterogeneous reaction system. Chem. Eng Proc., 46(3): 210-213.

Clemenitina MM, Artur MS, Jose AS. 2006. Epoxidation studies of 2-styrylchrommes using Jacbobson's catalyst and Hydrogen peroxide and iodosylbenzene as oxidants. J. Het. Chem., 43(5): 1310-1326.

Dinda S, Partwardhan AV, Goud VV, Pradhan NC. 2008. Epoxidation of cotton seed oil by catalysed liquid aqueous hydrogen peroxide inorganic acids. Bioresource Tech., 99(9): 3737-3744.

Espinoza P, Haagenson DM, Pryor SW, Wilsenborn DP. 2009. Production and characterization of epoxidised canola oil. Transactions of the ASABE. 52(4): 12891297.

Gall, Greenspan. 2012. Ion exchange resins to replace mineral acids in in-situ epoxidations. J. American oil Chem. Soc., 37: 449-453.
Gerd-Jan B, Bruno CM, Michael CA, Isabel WC, Roger AS. 2007. Selenium catalysed oxidations with aqueous hydrogen peroxide. J. Chem. Soc., Perkin Trans., 1: 224-228.

Golchoubian H, Nemati K. 2005. Hydrogen Peroxide oxidation of mono- and disubtituted alkylarenes catalyzed by dinuclear Co-III-Cu-II macrocyclic complex. Polish J. Chem., 79: 825-830.

Goud VV, Patwardhan AV, Dinda S, Pradhan, NC. 2007. Epoxidation of karanja (Pongamia galbra) oil catalysed by acidic ion exchange resin. Europ. J. Lipid Sc. Tech., 109: 575-584.

Goud VV, Patwardhan AV, Pradhan NC. 2007. Kinetics of in-situ epoxidation of natural unsaturated triglycerides catalysed by acidic ion exchange resin. Ind. And Eng. Chem. Research., 46(10): 30783085.

Goud VV, Patwardhan AV, Pradhan NC. 2006. Studies on the epoxidation of mahua oil (Madhumica indica) by hydrogen peroxide. Bioresource Tech., 97: 1365-1371.

Guodong D, Espenson JH. 2005. Oxidation of triarylphosphine and methylsulfides with hydrogen peroxide cataysed by dioxovanadium(V) ion. Inorg. Chem., 44(7): 2465-2471.

Hamid G, Farid H. 2007. Effective oxidation of Sulfides to Sulfoxides with Hydrogen Peroxides under Transition-metal-Free Condition. Molecules, 12: 303-311.

Latourette HK, Castrantas HM, Gall RJ, Dierdorff LH. 2012. A novel continous countercurrent epoxidation process. $J$. the American oil Chem. Soc., 37: 559603.

Lawrence DR, BenneH PN, Brown MJ. 1998. Clinical Pharmacology (8th edn). Churchill Livigstone: London; 484-94.

Leveneur S, Warna J, Salmi T, Murzin DY, Estel L. 2009. Interaction of intrinsic kinetics and internal mass transfer in porous ion exchange catalysts: Green synthesis of peroxycarboxylic acids. Chem. Eng. Sci., 64(19): 4101-4114. 
Mungroo R, Pradhan NC, Goud VV, Dalai AK. 2008. Epoxidation of canula oil with hydrogen peroxide catalysed by acidic ion exchange resin. J. American oil Chem. Soc., 85(9): 887-896.

Ojinnaka CM. 2001. Oxidation and Reduction in Organic Chemistry ( $\left.1^{\text {st }} \mathrm{edn}\right)$. University of Port-Harcourt Press: Nigeria; 13-43.

Petrovic ZS, Zlatanic A Lava CC, Sinadinovic-Fiser S. 2012. Epoxidation of soyabean oil in toluene with peroxy acetic and peroxy formic acids-kinetics and side reactions. Europ. J. Lipid. Sci. Tech., 104(5): 293-299.

Rao AS. 2012 Comprehensive Organic Synthesis $\left(7^{\text {th }}\right.$ edn $)$. Pegamon Press: Oxford; 357.
Rosana de Cassia S, Schneider LR, Lara S. 2009. Chemo-Enzymatic epoxidation of sunflower oil methyl esters. J. Braz. Chem. Soc., 20(8): 1473-1477.

Shangde S. Longlong C, Guolung Y, Xiadi X. 2011. Enzymatic epoxidation of sapindus mukorossi seed oil by perstearic acid optimized using response surface methodology. Ind. Crops Prod., 33: 676682.

Sheng MNA, Zajacek JG. 1970. Regioselective epoxidations of dienes with manganese(III) porphyrin catalysts. J. Org. Chem., 35: 1839.

Tayde S. Patnaik M, Bhagt SL, Renge VC. 2011. Epoxidation of vegetable oils: A review. Int. J. Advanced Eng. Tech., 11(4): 491-501. 